\title{
米国における図書館リーダーシップ研修プログラム
}

\author{
マーカム, ディアナ $\quad$ B. ${ }^{1}$ : 著 \\ 高木和子 ${ }^{2}:$ 訳
}

\begin{abstract}
著者抄録: この20〜30年, デジタル情報テクノロジーが図書館に大きな変革をもたらしている。そし て, 電子情報サービスをサポートする技術インフラも整備されてきている。こういった状況にあっ て図書館は, 利用者の情報ニーズに合った図書館サービスをどう決定していくか。図書館がデジタ ル革命を十分に利用するための諸方策はどうあるべきか。これらに対処することが図書館リーダー に求められており, またリーダーシップをどう高めるかは大きな課題であり, 関心事である。新し いリーダーを教育, 訓練するさまざまな開発プログラムが米国で出現しており, すでに実施されて いる。例えば, ACRL/ハーバードリーダーシップ専門講座, NLMのアソシエート・フェローシッ プ・プログラム, シラキューズ大学の夏期専門講座などである。著者はこれら9つのプログラムを紹 介する。加えて, 1999年に開始された, 大学図書館のリーダー, 管理者を対象とするフライ・リー ダーシップ専門講座についてそのカリキュラムと成果を詳しく述べる。また, 日本人も参加できる モーテンソン・センター国際図書館リーダーシッププログラムについても詳しく紹介する。

キーワード : ライブラリアン, リカレント教育, リーダーシップ, 研修プログラム, フライ・リー ダーシップ専門講座, モーテソン・センター国際図書館リーダーシッププログラム
\end{abstract}

\section{Training programs for library leadership in the United States}

\section{written by MARCUM, Deanna B. ${ }^{1}$ translated by TAKAGI Kazuko²}

\begin{abstract}
Author Abstract: In the last two or three decades, digital information technologies have brought a big transformation in libraries. Keeping pace with it technological infrastructure supporting digital information services has been arranged well. With this situation how do libraries make library services to meet users' information needs? What measures should libraries take to make full use of digital transformation? These are exact issues library leaders are required to deal with. Thus to raise leadership quality is not only a current issue but also a big concern. There are various educational or training programs for new library leaders have emerged in the US. For instance, they are the ACRL/ Harvard Leadership Institute, the National Library of Medicine's Associate Fellowship Program, and the Syracuse Summer Institute on Leadership and Changes in an Information Society. The author introduces those 9 programs. Then the author describes the program offered by Frye Leadership Institute since 1999 mainly for academic librarians or university administrators in terms of curriculum and results obtained from the program in detail. She also describes Mortenson Center International Library Leadership Program which the Japanese librarians are allowed to participate in.
\end{abstract}

Key words: librarian, recurrent education, leadership, training program, Frye Leadership Institute, Mortenson Center International Library Leadership Program

\section{1. 研修プログラムの新しいニーズ}

ここ20〜30年の間にデジタル情報テクノロジー
は, 米国の大学や自治体の図書館に変革をもたら し，それは現在も続いている。図書館の目録カー ドはデジタル化され，研究者や学生はキャンパス

1四書館・情報資源協議会 Tel. 202-939-4750 E-mail: dmarcum@clir.org ${ }^{1}$ Council on Library and Information Resources (1755 Massachusetts Avenue, N.W., Suite 500 Washington, D.C. 20036-2124 USA)

2科学技術振興事業団「情報管理」編集事務局気付（干102-8666 東京都千代田区四番町5-3）

${ }^{2}$ Japan Science and Technology Corporation (5-3, Yonban-cho, Chiyoda-ku, Tokyo, 102-8666) 
内の事務室, 研究室ないし学生寮から図書館の所 蔵資料を探すことができるようになった。いくば くかのテキストやイメージをオンライン化する実 験が行われ，それが大量の図書館資料をデジタル 化するという大規模なプログラムへとつながった。 そして主要な研究図書館は, 利用者からの要求が 高まっている各種の電子情報サービスをサポート する技術インフラの開発を開始した。

しかし, これらの変化とともに, 多くの疑問が 図書館のリーダーの胸にわきあがってきた。図書 館の所蔵資料が, 図書館外から今後ますます入手 できるようになると図書館はいったいどうなるの だろうか。ライブラリアンは, 新技術の到来や刻 一刻変化する技術的事柄に追いついていけるのだ ろうか。ライブラリアンは, 今でも維持コストの かかる従来の図書館機能にデジタル資料やサービ スを追加する財政的余裕が持てるのだろうか。ラ イブラリアンの役割は情報技術者や出版者, その 他の電子情報プロバイダの役割と合体できるのだ ろうか。このような変化の渦の中で, いったい図 書館はその優先順位や, 取り入れるべき技術, 提 供すべきサービス，そして満たすべき利用者ニー ズを最適に決定できるのだろうか。

リーダーシップは, このようにして重要な関心 事となった。伝統的図書館のリーダーは, デジタ ル時代に備えた研修を受けてこなかった。彼らは 図書や雑誌を購入し, 整理・配架し, 図書館を訪 れる研究者のために館内で助力をしてきた。大学 の学問や授業, あるいは地域社会の読書人や研究 者が利用できるよう, 立派な印刷体の資料を収集 することが彼らの目標であった。しかし, デジタ ル資料類は利用者がいるその場でアクセスでき, 電子ジャーナルや電子データベースは所有される よりかむしろリースされるものである。そしてど の図書館も, デジタル資料類を入手することがで きる。これまでのリーダーたちは, 増大する電子 末来の新しい要求に, 果たして適応できるのだろ うか。

図書館のリーダーシップに対する関心は，他の ところからも出てきた。米国では伝統的なライブ ラリアンですら, 近いうち数が足りなくなるだろ う。調查によれば, 1998年には米国の全有資格者 ライブラリアンの $57 \%$ が 45 歳以上であり, 米国全 図書館の館長の $40 \%$ は 年以内に引退する。新しい リーダーを比較的早急に育成しなければならず, また現在のリーダーも新しいリーダーと同様, 伝 統的図書館に影響を与える技術変革に対処できる
よう学ぶ必要があることは明白である。

このニーズを満たす助けとなる非常に多くのリー ダーシップ開発プログラムが, 米国に出現してい る。いくつかの例を次に述べるが, それらによつ て種々のリーダーシップ開発プログラムやリーダー シップ訓練へのアプローチを理解していただけよ う。その後, リーダーにリーダーシップの知識を 授けるというより,むしろ極めて新しい種類のリー ダーシップの奨励に力を注ぐ米国のリーダーシッ プ・プログラムについて, 少し詳細に記述する。

\section{2. リーダーシップ研修の例}

(1) ACRL /ハーバードリーダーシップ専門講座

米国の非政府・非営利団体である大学研究図書 館協会 (Association of College and Research Libraries ACRL) が, ハーバード大学の高等教育研究所 (Institutes of Higher Education) と協力して, 大学図 書館ライブラリアンのためのリーダーシップ専門 講座 (Leadership Institute for Academic Librarians) を 毎年開催している。この専門講座は, 大学の図書 館長や, 図書館長に直属する副館長 (associate university librarian）, 図書館学部長補佐（assistant library dean) といった肩書を持つ人たちを対象とす る。「定期的に上級レベルでの意思決定に携わり」, 図書館全体やその対外的関係に影響を与えている ライブラリアンも同様に参加対象となる。同専門 講座は，管理業務を熟考する時間をライブラリア ンに与える機会を提供すると言えよう。

専門講座は, マサチューセッツ州ケンブリッジ にあるハーバード大学のキャンパスで, 6日間にわ たる授業と討論で構成される。研修の目標は, 参 加者が自分の図書館をリードし, かつ運営する能 力を高めることにある。同講座の教授陣は, 参加 者が2つのキーとなる質問に答えられるよう指導す る。すなわち,「現在ならびに将来のチャレンジに 対処するのに自分の機関は果たしてうまく機能す るのだろうか」と「自分自身のリーダーシップは, それに対しどれほど有効であるか」。ここで取り上 げられる主題とは, 例えば企画, 変革に関する学 習, 組織戦略と改革である。

2002年の専門講座には117名が参加したが, 米領 サモアから 1 名とカナダから1名を除き, 全員が米 国国内からであった。次回の専門講座は2003年8 月3 8 日までの予定である。詳細はWeb サイト $<$ http://www.gse.harvard.edu/ ppe>を参照されたい。 
(2) Kennedy School of Governmentエグゼクティブ • プログラム

ハーバード大学では, John F. Kennedy School of Governmentがリーダーシップに関する数種類の「エ グゼクティブ・プログラム」を提供する。これら は特にライブラリアンのためのものでも, またラ イブラリアンに限定したものでもないが, 政府や 非営利機関の上級経営幹部の参加を歓迎する。こ れらのプログラムは，それぞれ2～6日の期間で行 われる。対象となるトピックは以下である。

・ 21 世紀に向けてのリーダーシップ: 混沌, 対立, 勇気

・エグゼクティブのためのリーダーシップ技量 : 一連のショートプログラム

・危機管理：異常時におけるリーダーシップの遂行

・ 女性と力 : 新しい世界におけるリーダーシップ

詳細は<http://www.execprog.com/programs.asp>を 参照のこと。

(3) ARLのリーダーシップとキャリア開発プログラ 4

米国とカナダにある主要大学の大規模図書館の ほとんどがメンバーである米国研究図書館協会 (Association of Research Libraries ARL)は,「リーダー シップとキャリア開発プログラム」を開催する。 参加者は, 北アメリカの研究図書館でその最高位 の地位につけない人種および民族グループに属す るライブラリアンに限られる。したがって，彼ら ライブラリアンが十分に昇進できるために必要な 技量獲得の研修を行う。研修期間は10日間で，こ の間,5日間の講座を2回受ける。Webべースの3コー スをとり,研究プロジェクトを行う。このプロジェ クトは,その成果を出版形態にして発表する。2001 ～2002年には米国のライブラリアン20名が参加し た。詳細は<http://www.arl.org/diversity/lcdp/index. html>を参照のこと。

(4) 米国国立医学図書館のアソシエート・フェロー シップ・プログラム

米国の国立医学図書館 (National Library of Medicine NLM）は, 生物医学分野における巨大な 研究図書館で, 70以上の言語で書かれた590万件以 上の資料を所蔵する。同プログラムは, ライブラ リアンが将来, 健康科学図書館や保健サービス研 究でその役割に備えられるよう奨学金を提供する。 2003年にNLMは, \$38,406の奨学金プラス医療保険 費を各8名に対し与える。フェローシップに選抜さ れた人は, ワシントンDCの郊外にあるメリーラン ド州べセスダ所在のNLMで9月から始まる1年間の
研修プログラムを受ける。

参加者は18単位の研修を受け, 情報管理に使用 される広範なテクノロジーや技量を勉強する。実 地経験と講義, 議論, および個人プロジェクトと 組み合わされているが, 対象となるトピックはい ずれもマネジメントに重点が置かれており, ワシ ントンDC地区の図書館見学も組み込まれている。 興味があればさらに翌年, 保健関連機関に所属す る図書館で経験を積むためのサポートを受けるべ く出願できる。

このフェローシップへの出願は, 図書館学修士 をすでに取得している米国市民に限られる。しか し, 1，2年のうちに国際的な要素が考慮されるか もしれないので, 米国以外のライブラリアンでも 関心がある人は, 今後このプログラムのWebサイ トをチェックされたい, と同プロジェクトの責任 者は言っている。Webサイトは<http://www.nlm.nih. gov/about/training/associate/index.html>である。

(5) 都市図書館協議会のエグゼクティブ・リーダー シップ・プログラム

米国の非政府·非営利団体である都市図書館協 議会 (Urban Libraries Council) は, エグゼクティブ・ リーダーシップ専門講座を実施している。その目 標は, 一般市民にサービスする都市図書館の新世 代のリーダーの養成である。個人というより，む しろ図書館単位でこのプログラムに出願するが, 合格すると，図書館はチームをこの研修に派遣す る。四書館は授業料と, ボルチモアおよびワシン トンDC地域で開催される講座開催地への旅費を払 う。専門講座の期間は10か月間で, リーダーシッ

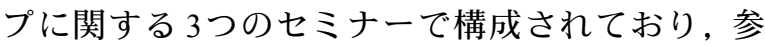
加図書館が現在直面しているリーダーシップへの 挑戦を検討し, 学び, さらに専門家講師陣による 継続的なサポートが得られる。

米国の民間財団が, 本講座にこれまで2回, 合計 約50の参加図書館チームに資金を提供してきた。 講座への出願期間は終了しているが, 講座内容等, 詳細は<http://www.urbanlibraries.org/eli.html >を参照 されたい。

(6) 情報社会におけるリーダーシップと変革に関す るシラキューズ夏期専門講座

ニューヨーク州シラキューズ市にあるシラ キューズ大学情報学部は, 情報社会におけるリー ダーシップと変革に関する夏期専門講座を同大学 で開催する。この講座はライブラリアンを含む情 報専門家向けで, 出願者は米国市民に限らない。

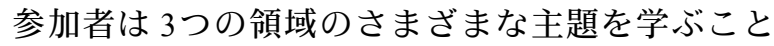


ができる。2日間のワークショップ（複数），5〜7 日間の講座（複数）から選択できる。3つの領域と は 1)リーダーシップ開発と管理 2) テクノロジー の応用 3) 利用者サービス, である。コースは学 部や大学院の単位にもカウントされる。詳細は $<$ http://www.istweb.syr.edu/academics/graduate/summer/ index.asp >。

(7) UCLAのシニア・フェローズ・プログラム

カリフォルニア州ロサンゼルス市にあるカリフォ ルニア大学ロサンゼルス校 (UCLA) は, シニアフェ ローのための夏期プログラムを開催する。このプ ログラムは, 大学図書館や研究図書館のリーダー である上級レベルのライブラリアン向けである。 毎年多くて15名のシニアライブラリアンが選抜さ れ, 同大学の夏期キャンパスで, 政策とリーダー シップに関する上級管理者向けの講座で学ぶ。2003 年度の出願はすでに終了しているが, 今夏は 8 月 11 〜29日まで開催される。極めて選抜が厳しい同プ ログラムは1982年に始まった。ちなみに米国外か らの出願も受け付ける。詳細は<http://is.gseis.ucla. edu/seniorfellows >。

(8) メリーランド大学公共図書館リーダーシップ専 門講座

ワシントンDC郊外,メリーランド州カレッジパー ク市にあるメリーランド大学情報学部は毎年, 公 共図書館リーダーシップ専門講座を開催する。全 米からの参加者は, 期間が $4 \sim 5$ 日間の「集中経営 研修」を受ける。本講座は, 公共図書館の館長な いしその他の上級管理者にとって重要と思われる 課題を取り上げる。参加者であるライブラリアン は, 自らの経験や問題点, および公共図書館の課 題へのソリューションに関する情報交換が行える。 米国外からの出願も受け付ける。2003年の開催は 計画されていないが, 将来的には再開されると思 われる。詳細は<http://www.clis.umd.edu/ce>。

(9) スノーバード専門講座および関連専門講座

米国で最もよく知られているライブラリアンの ためのリーダーシップ研修プログラムのひとつで あるが, 2003 年は開催されない。スノーバード . リーダーシップ講座は, 1990年に開始され, 以降 毎年開催されていた。この名前は, 専門講座が開 かれた米国西部のユタ州ソルトレーク市の近郊, 雪深いワサッチ山脈にあるスノーバードという名 のスキー場の名前から来ている。通常この講座は, 館種を問わず中堅のライブラリアンを, 毎年30〜 35名受け入れ, 彼らにリーダーシップの研修を行 う。いくつかの州では, 少なくとも暫定的にその
周辺の州にまたがるスノーバードのようなリーダー シップ専門講座をライブラリアンのために設定し ている。例えば, アラスカ州, ネブラスカ州, ネ バダ州, ノースカロライナ州, オハイオ州, テキ サス州などである。これらの専門講座は, スノー バード専門講座の実施を担当した企業である Schreiber Shannon Associatesを通常使って講座を開催 する。この企業は, ニュージーランドでも同様の オーロラ・リーダーシップ専門講座を開催している。

スノーバード専門講座の調査から次のような結 論が得られた。講座への参加とキャリアの向上度 との間の直接的な関係は確認しがたいが, 「調査回 答者たちはさまざまなカテゴリーでのリーダーシッ プ活動分野の活動レベルは上がったとしており, さらにこのリーダーシップ研修は役に立っている と見なしている1)。3つのリーダーシップ・プログ ラムを卒業し, 現在米国の都市の公共図書館の館 長を務めている人物が, 最近リーダーシップ研修 の利点を分析した報告書を出版した。彼は「これ らの専門講座がリーダーの育成に成功していると いうことを証明する具体的な証拠はない」と認め ながらも, 多くの研修卒業生が事実, リーダーに なっており, リーダーシップ専門講座から得たビ ジョン, 洞察力, そして「良き指導者と同僚の堅 固なネットワーク」は非常に貴重であると論じて (る2)。

\section{3. 新しい種類のリーダーシップ研修}

1990年代末, 米国での学術資源へのアクセスを 創設・提供するためにデジタルテクノロジーの利 用を促進する一方で, 伝統的図書館の適応能力に 不安を抱いていた我々の何人かは, 違う種類のリー ダーシップ研修を開催することが望ましいと考え た。問題は “図書館はどうなるのだろうか”では ないことに我々は気づいた。問題は“ライブラリ アンは, デジタル革命の利点を十分に利用するた めに大学の他の専門家と共同することができるだ ろうか”ということであった。そして, どのよう にしたら情報専門家たちによる共同リーダーシッ プを大いに進めることができるのだろうか。

これに対する我々の答えは, 毎年開催すること になるフライ・リーダーシップ専門講座（Frye Leadership Institute) を1999年に創設したことであっ た。フライ専門講座は, 現在, あるいはいつの日 か高等教育機関で学術情報の管理運営の変革の責 任者の地位に就くひとりひとりに，継続的な教育 
の機会を提供する。ライブラリアンだけでなく教 職員，情報技術専門家，大学管理者など，教育機 関にあって情報技術に従事するいずれの専門家で も参加できる。

専門講座には毎年40〜 50名が自鹰, 他薦で出願 し, 選抜制であるがその競争率は高い。彼らは高 等教育の場でリーダーシップに強い関心や才能を 持つ人々で, 高等教育を構成するさまざまな背景 や多様な経験技量を持つ。我々は特に,リスクを 進んでとろうとする人, 自分の周囲だけでなくそ の外側の環境にも理解を働かせることができる能 力のある人, 問題の解決に批判的かつ創造的な思 考能力を持つ人々の参加を望む。専門講座は米国 の高等教育に焦点を置くが, 日本のような外国か らの出願者も歓迎しており, 実際, これまでにア メリカ人以外も参加している。

研修は, ジョージア州アトランタ市にあるエモ リー大学で, 毎年6月に 2 週間の集中セミナーで始 まる。エモリー大学での研修の後, 参加者は実質 的には 1 年間, 参加者の属する大学, もしくは該当 する場所で実習科目を勉強する。この実習科目を 通して, 参加者はその属する機関環境の中で, 本 研修中にぶつかった課題であるとか疑問点に取り 組み,場合によっては属する機関の該当部署の人々 と共同してそのプロジェクトを行うこともある。 実習科目の勉強成果は, 翌年の短期セミナーにお いて参加者相互で発表し合う。本研修はサマリー セッションと呼ばれるもので締めくくる。このセッ ションは, 1 年間の参加者全員が集合して, 学んだ 内容を議論し, 評価する場である。

高等教育や社会で認められているリーダーを講 師とする講義を聞き，およびセミナーやグループ プロジェクト, 資料を通じて, 参加者は状況の変 化や複雑な高等教育が根源となって生じるリーダー シップへのもろもろの課題, チャレンジを勉強し 分析する。本研修は特に, 情報技術が研究の方法 論, 教育法, さらには学術コミュニケーション方 法を今後ますます変えていくという意味にも注目 する。

フライ・リーダーシップ専門講座は, 多様なバッ クグラウンドを持つライブラリアン間の幅広い交 流のためのユニークな機会を提供すると同時に, 参加者それぞれの体験を豊かにし, 高等教育が次 の世紀にうまく入り込めるよう動機づけをし, 鼓 舞し, 明確にできる, 新世代の大学図書館のリー ダーをつくり上げる。フライ・リーダーシップ専 門講座は，伝統的なマネジメントプログラムとは
異なり, 高等教育の戦略的変化に対処するために 求められる創造的なリーダーシップとその資質に 重点を置く。

専門講座は, エモリー大学の総長で前プロボス ト，そして高等教育の著名なリーダーであり，図 書館・情報資源協議会 (Council on Library and Information Resources CLIR）の前理事会メンバー のDr. Billy E. Fryeにちなんでその名前をつけた。 CLIRはワシントンDCにある独立した非営利団体 で, 情報へのアクセス, ただし公共財として記録 され，保存された情報へのアクセスを広げるため に尽力している機関である。CLIRとエモリー大学 は, EDUCAUSEとも共同して同専門講座を後援し ている。EDUCAUSEは, コロラド州ボルダーとワ シントンDCにオフィスを持つ非政府機関で, 情報 テクノロジーを知の部分に活用することを促進す ることで,高等教育を向上させるという使命を持っ ている。

本専門講座は, こういった機関が学術・教育事 業への情報テクノロジーの影響や, 教育・研究 情報管理, そして学術コミュニケーション相互間 にこれまで存在していた明確な境界があいまい化 してきたこと, および情報資源やサービスが, 従 来から機関(例えば図書館, コンピュータセンター, 博物館など）を越えて拡大し，それが教育事業に 浸透していることなどを評価してきたという，そ ういった作業の結果生まれたものである。これら の機関は,米国のRobert W. Woodruff Foundationから 同専門講座のための資金供与を受けている。

本専門講座の後援者は, 現代の高等教育の挑戦 と変化が新しい能力と展望を持ったキャンパスの リーダー, すなわち我々の歴史的事業に新しい枠 組みをもたらすことのできる専門家の必要性を生 み出したと確信している。フライ・リーダーシッ プ専門講座の目的は, 学術, テクノロジー, 経済, 公共政策, 学生, その他構成体との関係のダイナ ミックスをも含むこの枠組みを知らしめる課題へ の洞察力と理解を,明日の高等教育のリーダーシッ プに持たせることである。

\section{4. フライ専門講座のカリキュラム}

2003年夏期講座の暫定的なカリキュラムは, 同 講座の典型と言えよう。6月1日（日）の午後, 3か 所の後援機関の代表と, Billy Frye氏による挨拶で 開会式が始まる。続いて参加者が紹介され，その 後全員参加で開会レセプションと夕食会が催され 
る。

翌日, 月曜日のプログラムは, 本講座の共同責 任者であるハートウィックカレッジ学長Richard Detweiler と, 図書館・情報資源協議会会長Deanna Marcumが同専門講座を紹介する。Detweiler氏が,そ の後に高等教育の問題点, 傾向, ビジョンに関す

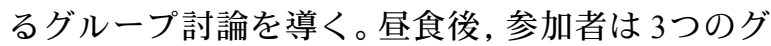
ループに分かれ, 各グループは「仮想機関」を想 定してそれが直面する主要な問題点を特定し, 確 認する。3つのグループのひとつは, ライブラリア ン, 2番目は情報技術者, 3 番目は教育と学習に携 わる人々で構成される。1日目のプログラムの最後 には, 学術調査コンサルテーションサービスの取 締役が講師で, 高等教育における変化についての 講義がある。

火曜日の午前中は, 大学の教員による講義「高 等教育の見通し」とそれについての討論が行われ る。午後は, 「学術事業における教育と指導と学習 の目標」「事業の共同カリキュラム学習目標」,「技 術と公共政策」の講義が行われる。

水曜日は, 上級レベルの大学管理者が講師の, 高等教育における現在の変化に関する「学術面な らびに管理面での展望」についての講義と, 著名 な教師や学者からの応答に充てられる。発表者と 参加者の間での討論がそれに続き, 参加者は自分 たちの実習科目プロジェクトに取り組むために小 グループに分かれる。

木曜日は, カレッジの学長 3 名が, その後の参加 者との討論に先駆けて,「学長の展望」を述べ, 4 番目の講師が, 高等教育に影響を与える政府機関 や法律についての「ワシントンの展望」を話す。夕 方に参加者は, エモリー大学の図書館情報資源セ ンターを見学する。

第1週は金曜日の講義「公共政策と高等教育」で 終了する。週末は自由行動で, その間アトランタ 地域のいくつかのツアーが組まれており, 自由参 加である。

第2週の月曜日は,「職場での個人のリーダーシッ プ」, 「財政問題の構造」,「リーダーシップのスタ イル」と題する講義と討論である。

火曜日は学術コミュニケーションが主題で,「学 者主導のコミュニケーションシステム」,「各学問 分野のコミュニケーションシステム」, 「学術コミュ ニケーションにおける変化への機関としての応答」, そして電子ブックプロジェクトに関する講義が行 われる。

水曜日は2名の教授が「指導と学習」について語
り，仮想機関を設定してその情報サービスを構築 するという小グループによる作業と, スキルワー クショップを行う。

木曜日はリーダーシップのスタイルについての 講義, 午後は「リーダーシップ検討セッション」で ある。実習科目に取り組む参加者のためのビジネ スランチならぬワーキングランチおよび送別夕食 会が組まれている。金曜日に, 同専門講座は評価 セッションをもって終了する。

期間を通して, 毎朝, 同専門講座の責任者であ るDr. Detweiler とDr. Marcumが, 前日に学んだ内容 を分析するための討論を誘導する。また, 参加者 には事前に関連資料が送られるので, それらを読 了したうえで参加することが求められており，ま た, 自分たちが直面している問題点について, そ の属する機関の主要なリーダーたちに実際に取材 ないし話を聞いてから参加することが求められて いる。

同専門講座の講師陣の経歴を含む, フライ専門 講座に関する詳細は<http://www.fryeinstitute.org/>を 参照のこと。

\section{5. フライ専門講座の成果}

1999～2002年までフライ専門講座は毎年開催さ れてきているが, 2003年の夏期講座のための願書 手続きはすでに終了している。このプログラムの 知名度は年々上がっているので, その結果, 競争 率が非常に高い。出願者は3年の間に2 倍に増えた。 同専門講座では, 大学で指導的地位に就く可能性 が高いと思われる人々を今後も選抜する方針であ る。第1回目の専門講座以来, ライブラリアン, 情 報技術者, コミュニティカレッジや教養課程の単 科大学や総合大学の教職員など, 合計132名の参加 を得た。一方, 講師陣について言うなら, 毎年36 〜 40名が同専門講座の講師を務める。

参加者はプログラム全体の評価を書くのに加え, 2週間のプログラムの間, 各セッションと講師であ る発表者ひとりひとりの評価も行う。毎年, プロ グラムは一貫して高い評価を受けている。昨年は, 2名を除く全員が専門講座に最高点の評価を与え た。その代表的なコメントを以下に記載する。

「これは実に大きな変化をもたらした経験であっ た。自分は総論的にはかなり知っていると思いな がらこの講座にやって来た。しかし物事について 多くを知ってはいても, それらを相互に結び付け て考えるには自分はかなり劣っていることに気が 
ついた。今では,ここに参加する前には理解でき なかった多くの事柄が相互にいくぶんかみ合って きたことが実感できる」。

参加者よりセミナーの経験から得たものについ てのコメントが笴せられ，それらから，まさしく いくつかのテーマが浮き彫りになった。そして, 予想されることではあるが, 通常の業務や仕事上 の懸案事項から開放され，2週間も新しい環境で新 しい人々に会い, 新しい考えに浸るのは確かに心 が弾むことである。「再活性化」,「動機づけ」,「充 電」,「再生」といった言葉が参加者の評価に頻繁 に見られた。相応して, 参加者の多勢が他の参加 者との「友情」と「協調」を発展させられたと語つ ている。彼らは互いに, 今後の仕事上の助けとな るネットワークをつくれると期待している。また， 共通していることは, 参加者はいずれもこの専門 講座で, 情報専門職の仕事のより大きな構想を身 につけたと感じており, そのうちの何人かは有能 なリーダーになるための, その能力という点で大 きな自信がついたと述べている。参加者の専門職 的, 個人的結び付きと同様に, 専門講座の講師陣 から得た理論とテクニックの結び付きを得られた ことが, 高く評価されている点である。さらに本 専門講座では, オーストラリア, 南アフリカ, ヨー ロッパの4か国からの海外参加者が含まれたことも 評価されている点である。前述したように, 日本 からの候補者の推薦も今後期待されている。

本専門講座の卒業生が学術機関内の情報課題に 関してリーダーシップを発揮する際に，どれほど の長期的影響を持つかを結論づけるのは，もちろ ん早計である。しかし, 最初の 2 年間に参加した人 たちは全員が実習科目を完了しており，それはそ の属する機関内で何らかの実習科目ならぬプロジェ クトの共同につながったことは確かである。高等 教育機関の学長やプロボストは, その機関から参 加した人々がプラスの効果をもたらしていると話 している。また，人材斡旋会社が図書館長やchiefinformation-officer（情報総括者）を探す場合も，本 専門講座に相談をしてくる。そしてより明示的な ことは, 過去 2 年間の参加者のうち少なくとも半数 は, 講座参加後, その属する機関でこれまで以上 の責任を実際に担っていることである。

本専門講座は合計 10 年間継続することが計画さ れており，それまでに米国学術機関の情報専門家 の中にあって有能で協力的なリーダーシップを発 揮する500名程度の「変革の推進者」の中核グルー プを準備し，鼓舞したいと考えている。

\section{6. モーテンソン・センター国際図書館 リーダーシップ・プログラム}

我々は, 特に日本の図書館関係者にとって興味 深いと思われるひとつのプログラムを設定した。 モーテンソン・センター国際図書館プログラム (Mortenson Center for International Library Programs) が それで,このプログラムはイリノイ州シカゴの南, シャンペーン・アーバナに所在するイリノイ大学 の広大な図書館に置かれている。モーテンソン . センターの目標は, 世界中の図書館やライブラリ アンの間での国際的な連携を強化することである。 特に, センターは海外のライブラリアンや情報専 門家がプログラム終了後, その属する機関に戻っ てから研修を行えるよう必要な技量を与えるとい うアソシエーッ・プログラムを設定した。すでに 76か国, 500名を超えるライブラリアンがこのプロ グラムに参加した。2001年に図書館・情報資源協 議会（CLIR）は，モーテンソン・センターと公式 に提携を結んでプログラムの追加内容を作成した。 すなわち, モーテンソン・センターのアソシエー ツ・プログラムに参加する海外のライブラリアン のためのリーダーシップコースを追加した。この コースは現在実施されており, その期間は5日で, 次のようなカリキュラムで構成される。

初日, 参加者は本講座の全体像とその目的を学 び，グループ実習に参加する。

翌日, リーダーシップの全体像，すなわち，さ まざまなリーダーシップのスタイル,リーダーシッ プについての見解, 管理を重視したリーダーシッ プと管理より，むしろ相手をリラックスさせられ るような，自発的行動を促すようなリーダーシッ プの違いを学ぶ。参加者はその後, 小グループに 分かれてリーダーシップの定義やそのレベルを議 論する。午後は, リーダーシップのスタイルに影 響を与えるリーダーのパーソナリティを知るため に行動分析の作業を行う。参加者は自らのリーダー シップについて, 次のような質問を問いかける。

・自分自身をリーダーとしてどう見るか 1つ以上のリーダーシップのスタイルがとれる ほど自分はフレキシビリティがあるか 特定の目標あるいは現実の作業に応じてそれぞ れの人々にあった別のリーダーシップのスタイ ルを自分は使い分けているか

自らのリーダーシップのスタイルは状況のニー ズにとってふさわしく, また合致したものであ るか 
・リーダーとしてうまくやれる, および効果的に やれるという能力を自分は持っていると認める ことはできるか

3日目に, 参加者は, 今日の世界における図書館 とライブラリアンの役割, それらに立ちはだかる 課題と可能性, 米国におけるライブラリアンシッ プというステータスについて学ぶ。その後参加者 は，参加者それぞれの国や地域における図書館と ライブラリアンの役割や, そこで直面する課題に ついて議論する。午後は, チームづくりとコミュ ニケーション・スタイルについての議論, 事例研 究に専念する。

4日目は, リーダーシップのためのマネジメン ト・スキルを集中的に取り上げる。ここで議論さ れるスキルとは, 例えば戦略的計画, 政策開発, 図 書館におけるテクノロジーの利用, 人事管理, コ ミュニケーション, 財政計画と開発である。参加 者はまた, 図書館における政策設定の場とその重 要性も学ぶ。すなわち, 知的自由, アクセス, 保 存, 知的所有権, テクノロジーに関する諸政策が 対象となる。
最終日, 図書館のための提唱活動を扱う。図書 館のミッション・ステートメントがなぜ有益なの か, 奉仕するコミュニティの中で, 図書館の使命 やサービスをいかにして促進するか, についての 講演がある。ニュースメディアと効果的に共同す るための研修も含まれる。参加者はまた, 米国図 書館協会 (American Library of Association ALA) が 展開する実際の提唱キャンペーンの概観について の話も聞く。そして該当するなら, どういう応用 が米国以外の国にも使えるかを話し合う。本コー スは,評価セッションと終了を祝う夕食会で閉じる。 モーテンソン・センターのリーダーシップ・プ ログラムが有用であると思われた日本のライブラ リアン諸氏の, 本プログラムへの参加をぜひ呼び かけたい。このプログラムの詳細は<http://gateway. library.uiuc.edu/mortenson>を参照のこと注1。

注1) 私立大学図書館協会は, モーテンソン・センターと 協定を結び, 協会加盟館専任職員1名に対して, 2003 年8月に行われるアソシエーツ・プログラムへの海 外派遣研修を実施する予定である<http://www.jaspul. org $/>$ 。

\section{参考文献}

1) Neely, T.Y.; Winston, M.D. Snowbird Leadership Institute: a Survey of the implication for leadership in the profession. College and Research Libraries. Vol.60,
No.5, 1999, p.412-425.

2) Nichols, C.A. Leaders born or bred? Library Journal. No.127, 2002, p.38-40. 